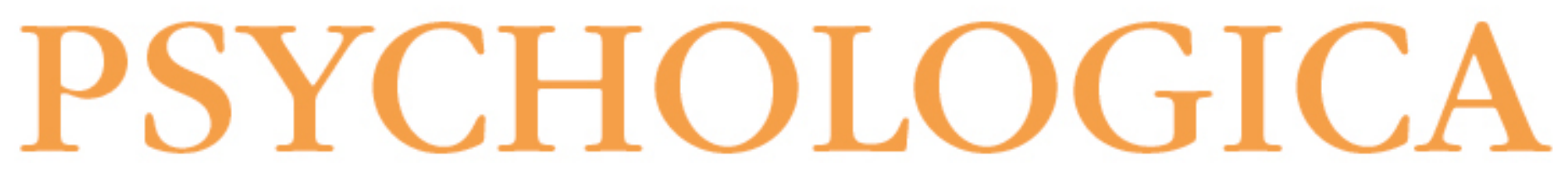

The challenges of Social Work education in Europe

Autor(es): $\quad$ Campanini, Annamaria

Publicado por: Imprensa da Universidade de Coimbra

URL

persistente: URI:http://hdl.handle.net/10316.2/3491

DOI: $\quad$ DOl:http://dx.doi.org/10.14195/1647-8606_52-2_30

Accessed : $\quad$ 26-Apr-2023 06:48:07

A navegação consulta e descarregamento dos títulos inseridos nas Bibliotecas Digitais UC Digitalis, UC Pombalina e UC Impactum, pressupõem a aceitação plena e sem reservas dos Termos e Condições de Uso destas Bibliotecas Digitais, disponíveis em https://digitalis.uc.pt/pt-pt/termos.

Conforme exposto nos referidos Termos e Condições de Uso, o descarregamento de títulos de acesso restrito requer uma licença válida de autorização devendo o utilizador aceder ao(s) documento(s) a partir de um endereço de IP da instituição detentora da supramencionada licença.

Ao utilizador é apenas permitido o descarregamento para uso pessoal, pelo que o emprego do(s) título(s) descarregado(s) para outro fim, designadamente comercial, carece de autorização do respetivo autor ou editor da obra.

Na medida em que todas as obras da UC Digitalis se encontram protegidas pelo Código do Direito de Autor e Direitos Conexos e demais legislação aplicável, toda a cópia, parcial ou total, deste documento, nos casos em que é legalmente admitida, deverá conter ou fazer-se acompanhar por este aviso. 


\section{NÚMERO 52}

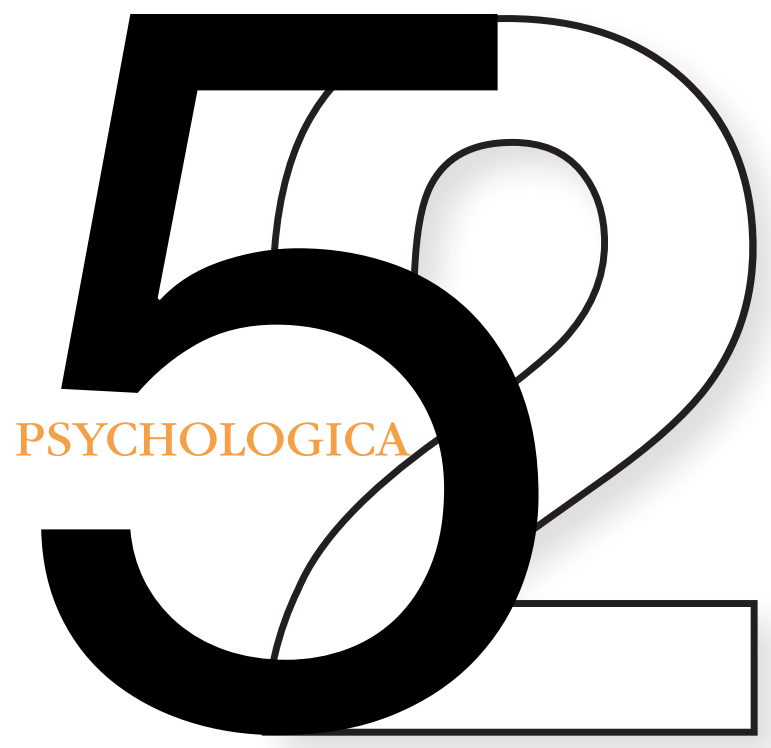

VOLUME II

IMPRENSA DA UNIVERSIDADE DE COIMBRA

FACULDADE DE PSICOLOGIA E DE CIÊNCIAS DA EDUCAÇÃo DA UNIVERSIDADE DE COIMBRA 


\title{
The challenges of Social Work education in Europe
}

\begin{abstract}
Annamaria Campanini ${ }^{1}$
In my presentation I will explore the situation of social work education in Europe, looking at the challenges of the XXI Century, underlining the effects and the demands arising from the application of the Bologna process and stressing the importance of developing innovative experiences in training, that focus more on competences and on an international dimension in education.

Social work education initially grew in Europe at different stages from the beginning of XX th century till the end of the second world war, but also had a new and important "rebirth" after the crash of the communist regime in the central eastern part of Europe. In the last two decades the creation or re-opening of social work education in eastern European countries has been of considerable significance. What does 'social work' mean today and what currently are the social professions being referred to in different European countries? Authors like Lyons, Lawrence (eds.2006) and Lorenz (2006), among others, deal with the topic of social professions in Europe, with a particular focus on the role covered by education in preparing social workers. Education in social work is worthy of such a sustained focus, because of its unique nature in reflecting specific cultural and contextual dimensions. Historical backgrounds, social policy trends, pedagogical and disciplinary relationships and 'politics' all have implications for the way in which training in social work has been established in different countries. Local factors and European policy developments are all important elements in determining in what way social work education is evolving in terms of structure, curricula and pedagogical issues.
\end{abstract}

\section{1-The state of the art}

Many initiatives have been taken during the last decade in social work education, and our intention here is to offer an, albeit impressionistic, overview of the situation of social work education in Europe, from different actors in the field. We can refer to some that have involved many different countries, such as the thematic networks ECSPRESS (1999) and EUSW (2002/2008). In both of this experience many 
European representatives have been active and gave their important contirbution. In the book 'European Social Work. Commonalities and Differences' (Campanini, Frost 2004) representatives of 24 different European nations presented the 'state of the art' of social work in their countries. Through this work it was possible to have a clear image of some commonalities and also many differences in social work education at different levels. Other research has been undertaken following this, for example by Martinez (2007), specifically on social education in the wake of the Bologna process and structures across Europe and on fieldwork education/ placements in fifteen European countries (Campanini, 2009).

From these studies it is evident that meaningful differences between European countries persist in a number of ways:

- in the kind of institutions which provide this education. Besides countries that have entrusted the formation in more or less recent times to the university sector, there are countries that have also developed learning routes in higher private or public institutes. In some nations (such as Poland, Lithuania, Portugal) there is the simultaneous presence of various educational contexts. The church has significant involvement in social work education in Eastern European countries such as Hungary and Romania where the social work training can be linked with the preparation to become a deacon.

It is also important to note how the type of educational context can influence the consideration given in the society to the title, 'social worker', and how it is linked to the relevance and meaning that are attributed to every type of formative institution in the various nations. It is interesting to note how the insertion into the university rather than in other contexts, not only produces one different legitimation of the social worker role (as happened in the Italian experience), but also leads to a more or less elevated status of the profession. Moreover, access to advanced courses (e.g. research doctorates) can be more difficult if the students have not undertaken a university degree, but have attended educational institutions such as the Fachhochshulen in Germany or the Hogeschoolen in the Netherlands.

- in the duration of the training/education period. In some places, at the time of the first research done in the EUSW context, there were curricula of only three years for example in Spain and in Belgium, while other countries responded, in accordance to the guidelines issued by the Bologna Declaration and social work education, articulating the educational path in a three years-plus-two years pattern (e.g. Italy, Norway, Estonia). Some states maintained a curriculum of four years (the Netherlands, Greece, Cyprus, Germany, Iceland) while in other countries the title of social worker was awarded after the attendance of a five year course (Portugal). At the present many changes have happened due to the 
need to restructure the education path in accordance with the Bologna Process and the situation appears still fluid and in a continuous change, but not always having successfully harmonized the differences of duration of the first and the second cycles (eg. Sweden decided for a $3+2$ pattern, while Spain defined the curriculum in $4+1$ ).

- in the disciplinary components of the curricula. It is generally true that the disciplines which form the base of social work education make reference to the human sciences of sociology, psychology and pedagogy. These are placed side by side with social policy and legal studies. In some Eastern European countries, such as Romania and Hungary, theology is studied. The different emphasis given to these disciplines prepares students to undertake different roles and contributes to professional differentiation. Where some countries show an awareness of counselling and therapeutic social work activities (such as the Scandinavian countries), others focused their contribution on educational and pedagogical issues (such as Germany, Poland, Luxembourg and the Netherlands).Some countries give specific attention to community and youth work or probation (Great Britain); others follow a more generalist approach in social work (Italy, Finland). Some countries discuss activities more connected with practical and economic help (many Eastern countries such as Estonia and Lithuania, where there is a major fight against poverty), or with advocacy (social advocates in the Netherlands) and work (occupation, employment) problems.

- in professional practice preparation - variously referred to as 'placement', 'fieldwork' or 'practice education' -there are many differences both in relation to the number of hours dedicated to social work theory and supervised practice and regarding the modalities within which the training is carried out.

In a recent analysis (Campanini, 2009) of 18 curricula in 15 different European countries we found a variation of number of hours dedicated to field placements from 2050 ( in France) to 210 (in Estonia) with a different criteria in the definition of the relationship between number of credits and number of hours. Also different is the articulation of this experience along the curricula: some times the field placement is full time in one block (Sweden, Germany) but in many other countries it is spread throughout the whole curricula with some amount of hours for each year. Differences are also evident in the role of other personnel involved with the student in 'placement' experience: supervisor, tutor, practice teacher, field instructor are some of the different names with which the same function can be designating, or in other cases these titles designate the specific roles being played by the same person. Further differences are notable in the evaluation processes that can range from being quite general and not impacting greatly on the attainment of the degree, regardless too of the quality of the experience 
(for example in Italy) to being strictly regulated in terms of quality, learning and student achievement, (e.g. G.B.).

- In relation to teaching methodologies. The role of teachers on social work courses can be quite different and is strictly related to the idea of "learning process" predominant within a national context. Active learning has a very strong background and presence in Scandinavian countries, with specific tools and evaluation processes more oriented to help the student to be the principal actor in their own learning process and to develop a critical and self reflective attitude. Contrary to this, in Italy more conventional methods are used, based on: the traditional notion of an expert lecturer imparting knowledge to educable and eager students. Interestingly within specific systems even the layout of rooms can reinforce the specific philosophy. In Italy it can be very difficult to find flexible shapes and settings away from the formal auditoria which restrict teachers in allowing the development of more participative methods. ITC technologies are slowly entering into social work education, for example in the Norwegian led initiative of a virtual classroom: 'Virclass' and are very useful for organising paneuropean modules with mixed teachers and students from different countries (see the Virtual Campus experience www.virclass.net).

- In research and theory production. These aspects are mentioned as important elements for the enhancement of social work education. In some nations, such as Sweden, a long tradition of PhD studies links to intensive publication of research in social work. In some other countries (e.g. Estonia, Czech Republic, Italy and Spain) this process is seen as a fundamental challenge for the future of social work. There are problems linked with the positioning of education in social work inside or outside the university, both in relation to having the possibility of students achieving research degrees, and also in relation to the expectation that teachers will be research active (Lyons, 2006).

- In the European orientation. Involvement and participation in European projects and activities is rather high in nearly all countries and In various ways social work has been pursuing and realizing the aim of opening itself to inter-European comparisons in social work education. In many countries the opportunities made available by the European Community (such as Erasmus, Socrates, Leonardo) are being used. Many countries have involvement in student mobility and teaching staff exchange.

These activities have also been developed in some places in relation to periods of intensive study on specific topics (such as the intensive programs) and to the particular initiatives such as international weeks, which are open to contributions from teachers of various nations. The attempt to open education to a wider vision is also demonstrated by the insertion within the curricula of modules that address 
various aspects of social work from a comparative perspective. There are some interesting experiences of summer schools (eg. FachochSchule Alice Salomon in Berlin, Yliopisto University in Rovaniemi, Finland, but also the ones held in Parma and in Dorbirn by the EUSW TN), some international master courses (MACESS in Maastricht, Goteborg University, Berlin, Lisbon) and also some attempt to create a specific course which awards the title of 'Bachelor of intercultural and international social work' (as in Copenhagen). In spite of these initiatives, some difficulties still remain. Primarily these are: the students and staff's insufficient knowledge of languages (eg. France, Great Britain, Italy, Spain); problems of the temporal structure of the courses and the economic costs of studying abroad, all of which can limit the mobility of the students. Some reluctance to operate transnationally might also be pointers of an inward facing attitude, whereby European engagement and dimensions are still not perceived as opportunities. Students then fail to develop intercultural and international professional competences, which are now seen as core competencies in many parts of Europe.

\section{2- The Bologna Process}

Currently we are witnessing a particular phase within higher education. Since the 1980s, the European Commission has defined a series of measures with the key objective of developing and improving the European component within the teaching world, alongside further enabling the geographical mobility of students. The Socrates and Erasmus mobility programmes have had, and are having, without any doubt, great impact upon the creation of a European identity; they have helped develop better understanding of any underlying problems, and have encouraged a shared knowledge base to evolve. One of the needs identified, a need which moved the European Union to highlight the importance of an intercultural dimension within student learning, has been the need to prepare younger generations for life in a society increasingly characterized by cultural and linguistic diversity, so that they may identify concrete actions with which to fight racism and xenophobia. The Socrates Erasmus programme measures have made possible to enhance the student mobility and the ECTS system, to develop Joint Programmes to encourage academic acknowledgment and contribution toward the exchange of experiences and innovation processes, therefore enhancing the quality of teaching; to support teaching staff exchanges and intensive programmes.

Through the Bologna declaration (1999), an initiative of 29 European Governments, a process was established, with the objective of creating a European Space of Higher Education by 2010. The aim was to increase both the employment pros- 
pects and geographical mobility of European citizens, and enhance the concept of European higher education in the world. This required a concrete shift towards:

- Easily readable and comparable systems of degrees

- The creation of a structure founded upon two cycles (BA \& MA), using the 692 European credits system (ECTS)

- Promotion of geographical mobility for students, teachers, researchers and administrative staff, and recognition of experiences within a European context - European co-operation in quality assurance with a view to develop comparable criteria and methodologies.

The Bologna Declaration has been followed by three communiqués: Prague (2001), Berlin (2003) and Bergen (2005). Each of these steps brought further developments in the harmonisation process, and highlighted different aspects. The Prague Communiqué stressed the importance of lifelong learning as an essential strategy within the European Higher Education Area; enabling social work to face the challenges of competitiveness and new technology, whilst also improving social cohesion, equal opportunities and quality of life. The Berlin Communiqué emphasized the importance of research, alongside research training and interdisciplinarity, in maintaining and enhancing the attractiveness of higher education in Europe. Another aspect highlighted was the need to develop an agreed set of standards, procedures and guidelines relating to quality assurance, to ensure an adequate peer review system had been put into place. Connected with the topic of comparability, the communique invited the member states to develop a framework of comparable and compatible qualifications for their higher education systems, which would seek to describe qualifications in terms of workload, level, learning outcomes, competences and profile. It is also interesting to note the fact that the different levels of degree should have different orientations and varying profiles, in order that they accommodate a diversity of individual, academic and labour market needs. First cycle degrees should give access, in the Lisbon Recognition Convention sense, to second cycle programmes. Second cycle degrees should give access to doctoral studies. The Berlin Communiqué recommends the introduction by 2005 of a universal "diploma supplement"; this must be annexed to each certificate. The intention being, to facilitate recognition of titles across all European countries, in accordance with the Lisbon Convention (1998). In the diploma supplement, the types of institution for example, and the level of the degree, are described in greater detail, allowing both greater confidence and comparability between countries.

An important step within this harmonisation process could be identified through the "Dublin Descriptors"; the product of an informal group of specialists originating from different countries, who unite under the banner of "The Joint Quality Initiative" (www.jointquality.org). The expected attributes of a student are 
clarified within these descriptors. Knowledge and understanding, application of this knowledge and understanding, making judgements, communication skills, learning skills: this list further refines the description of the expected attributes of a student. These specific qualities are graduated and matched to the demands of the perceived successful completion of the first, second and third Bologna cycles, and highlights the progressive steps between these cycles. In many countries, discussions of the changes required to revise the educational systems in order to meet the demands of the Bologna process, let alone the action required to implement these, are still ongoing. Yet in parallel, at the end of 2000, the project 'Tuning Educational Structures in Europe' was submitted to the European Commission, and is still working toward an overall objective of implementing discussion and reflection upon the changes Bologna has brought to educational structures and study content. The process of reforming, instead of a direct effect of the political decision making of education ministers to converge, requires a 'tuning' of curricula, in terms of structures, programmes, and actual teaching. Although is very important to protect the rich diversity within European education, at the same time, it is necessary to identify competences and learning outcomes, and to design, construct and assess the qualifications provided throughout this education. Four lines of approach have been developed:

- generic competences

- subject-specific competence (skills, knowledge and content)

- the role of ECTS as a transfer and accumulation system

- approaches to learning, teaching, assessment and performance in relation to quality assurance and control

The final reports 1 (2003) and 2 (2005), from the Tuning project, contain guidelines and practical examples. Of great interest to social work could be the specific analysis made of nursing education, which contains many similarities, and has therefore considerable potential for transferability.

An aspect of considerable importance is that of quality assurance. 'The European Network for Quality Assurance in Higher Education' was established in 2000, in order to promote European co-operation in the field of quality assurance. In November 2004, the General Assembly transformed the Network into, the European Association for Quality Assurance in Higher Education (ENOA). The idea of the association originates from the European Pilot Project for Evaluating Quality in Higher Education (1994-95) which demonstrated the value of sharing and developing experience in the area of quality assurance.

The Bergen meeting of the education ministers (2005), see above, took note of the significant progress made in three priority areas: the degree system, quality assurance, recognition of degrees and periods of study. The communiqué emphasized 
the importance of higher education in further enhancing research, and stressed the importance of this research in underpinning higher education, bringing economic and cultural development within our societies, and providing social cohesion. It is also noted that efforts to introduce structural change and improve the quality of teaching should not detract from the effort to strengthen research and innovation. As was explored in the recent book, Social Work in Europe: Educating for change (Lyons and Lawrence, 2006), the past two decades have witnessed significant changes, not only in the construction of Europe, but also within the education of the social professions in many countries. This changing process also affected social work education, though the consequences were different. On the one hand, it provides a strategic opportunity to augment professional growth and progress within social work. As Juliusdottir (2006) argues, through a reflexive process of becoming more academic, conditions are created for a dialogue to emerge between social work and academic culture, which could lead to interdisciplinary understanding and mutual respect. Being a part of the culture of other academic disciplines facilitates fresh motives for training and active participation in the social worker's own knowledge production through research and other theoretical activity, bringing social work both confidence and status in society. Lastly, this may also lead to both increased compatibility and mobility in times of increasing globalization and shared labor markets. Christine Labonté (2004) also emphasizes the possibility, which emerged through the introduction of a tiered academic structure, of retaining a generic program at Bachelors level, then providing a greater degree of specialization, required particularly for the new professional fields, by offering specially tailored Masters programs. The 'advanced' study program is thus conceptualised as part of specific 'skilling' or reskilling and lifelong learning. However, one simultaneous disadvantage of the three plus two structure is that it contains, 'the danger of reducing the professional element of training, by subjecting it to purely academic quality criteria, and what is more, academic criteria that are largely not defined from within an 'indigenous' discipline' (Lorenz, 2006, p.54).

Other problems might arise from the differing levels of importance accorded to the BA and MA in different countries; connected to the historical and cultural context of education in each country. Moreover, one set of trends would promote the awarding of the social work qualification after an overall five year academic package, whereas the other views the MA as an area for specialisation, often connected with 'advanced' (for example, managerial) tasks. On a connected but somewhat different point, Walliman (2004) emphasizes the dangers of an educational structure too exclusively responsive to, and tied up with market needs. He links this with the dangers of out and out competition between education providers, which might lead to a process of privatisation within education, analogous with the suggestions driven by the General Agreement on Trade in Services (GATS). 
This could lead to a creation of university programs for elites with higher level of costs and less offer of equal opportunities of access for everybody.

\section{Global challenges}

In Europe we are facing different challenges: the ageing of populations with both the risk of exclusion from participation in mainstream society, and also problems connected with care for illness, disability or loneliness; migration processes with their controversial and complex effects and their impacts on societies in terms of social inclusion and the embracing of diversities; the effects of globalization in lifestyle; relationship structures that can cause individual and family problems; the poverty that is still present in many countries; managerialism and its influence on the organization of welfare systems. Taking into account these challenges, social work has to deal with a general shift from state to civil society, from welfare to workfare logic, with an increased presence of third sector and no-profit social services and a service delivery market. The impact of globalization at local level requires "cross-cultural understanding, comparative social policy, concern with global problems, a general worldview, knowledge of a common profession worldwide, international practice, intergovernmental social welfare, and a sense of collegiality with social workers in other countries" ( Healy 2001).

An interesting suggestion comes from Askeland \& Payne (2008) who refer to the experience achieved in the Nordic countries where in the creative project leader education is offered special training in "driving through the chaos." As per the experience shown by the Institute for Social Inventions students who after a year in Denmark, are sent to San Francisco and then the next year to Beijing. The objective of this training methodology is to help the student to face new situations, to relate to different cultures, traditions and organizations, and also to orientate them in situations characterized by historical, economic, political and social conditions other than their own. This project might not be directly applied to our social work education but there might be opportunities, smaller in terms of time, but just as useful in developing professional competences in facing the fluidity and the critical issues of our social context. The various opportunities offered by mobility projects planned by the European Union and the effects of which I discussed in other contexts (Campanini, 2009), can provide especially useful stimuli for considering the effects of globalization, even on local levels, to get used to recognizing and respecting differences, and to create the feeling on the student of being foreign. There is a need to focus our education more then on the transfer of knowledge, on the ability to generate and process information, in order to integrate and embed 
the theory in the understanding of the practice, creating environments where learning can emerge through processes of reflexivity. The student, in this way will be able to manage the uncertainty, to move towards development prospects, maintain a balance between reflection and action, and then to transfer learning from one situation to another.

Another point which is also underlined in the document on Global Standard is the importance of the inclusion of cultural, ethnic diversity and gender issues in the training.

'Racialised' identities, are considered by Lena Dominelli as new challenges for Social Work Education. Focusing on anti-racist social work, the author proposes a model useful in helping students in "focusing on their own individual agendas" [2006, p.100] and working on these personal concerns. Starting from this point, she argues, it is possible to facilitate a deeper understanding of the meaning of difference, diversity, structural inequality and thus orient them towards an antiracist practice. As pointed out also by Tesoriero (2006), to develop awareness and intercultural skills it is necessary to go through a journey of personal and professional growth that helps to recognize their own ethnocentrism, by comparison with a clear ethical perspective and a reflective practice

This value-oriented, people-centered focus of the social worker should result in a professional attitude aimed to offer services tailored to meet significantly different needs of users, with the aim of reducing inequalities and possible discrimination already in place. It is important to recognize the differences within the social context in which they work and appreciate the contribution that can lead to the development of the community, but also pay attention to possible inequalities in terms of power, privilege or welfare (Friesenhahn, 2009). The international literature of social work is rather rich in theories and references to that effect. (Darlymple \& Burke 1995; Dominelli, 2002; Thompson, 2006) Another topic that should be given special attention is related to the promotion of human rights and social justice. Though this aspect is present in the international definition of social work, Silvia Staub Bernasconi, in her invitation to the seminar "Human rights in teaching and practice" that preceded the European Conference in Dubrovnik (April 2009), stressed that there was still a lack of focus on this issue in social work education. To confirm this, we can cite the provocative words of Dominelli, who titled a chapter in a Reichert (2007) book Human rights in social work practice: an invisible part of the social work curriculum?. To avoid pointing the finger just against violations of human rights in countries outside Europe, Staub Bernasconi, honored in the World Congress of Hong Kong (July 2010) with the Katherine Kendall prize, asked to reflect on some phenomena such as the increase of the gap between rich and poor, rising unemployment in many 
European nations, the inhuman policies towards refugees, trafficking of women and exploitation of children, growing nationalism and racism, and ethnocentrism of the social policies of the richest countries. All these issues present challenges for social workers and require a solid preparation. As an example of very advanced educational experiences that emphasize the theme of human rights, one can cite the international master "Social work and human rights" established by the University of Gothenburg in August 2008 and "Social work as a human rights profession ", organized in 2002 by Alice Salomon Fachhochshulen Berlin, together with the Humboldt University.

Within the European context this kind of experience, needs to be improved and structured in a more regular way in our curricula, to be able to enhance the level of social work, helping both teachers and students to develop the kind of intercultural attitudes so necessary in this new century. As Walter Lorenz states: "Internationalising social work means critically questioning the conventional boundaries of solidarity, questioning the ideological assumptions, dressed up as economic arguments, behind measures of exclusion, pushing out the boundaries of solidarity beyond the European to a global perspective and ultimately contributing to a shift from the welfare discourse to the human rights" (Lorenz 1994, p. 168/169).

Given these perspectives, the use of competences and modularization structure in the social work training curricula can become an important tool. Leaving the logic of teacher oriented processes and shifting the paradigm to student learning process is very important. This can improve their reflective and critical attitudes and their ability to connect theory and practice in a knowledge spiral. Work on competences is something very different to simply teaching skills. It involves knowledge, insights, skills and attitudes which can be used in a professional setting to handle different situations.

Modularisation requires the integration of different disciplines in relation to research, methodology and practice, not only a mixture of a variety of discourses related to the subject.

In this scenario there is a great need for a committed social work in communities to support personal and social responsibility and to contribute to social cohesion. It requires social workers who are able to invest in the development of resources of individuals and of local communities, involving all the major participants in elaborating and verifying processes and the means of constructing actions, able to work with whole subjects and not simply user categories, to engage fully with their points of view and their systems of thinking.

The key questions this raises, then, are : how to teach students to face this complexity; how to improve their own consciousness and ability to respond at 
the social work mission to enhance human rights and social justice; how to help students to acquire a non bureaucratic attitude and to develop a 'political' role in the most useful sense of the term?

The problem is, as Morin (1977) states, "transforming the discovery of complexity into a method of complexity".

But there is one last consideration to make: if social services wants to be an active player in the restructuring of welfare systems in Europe it must rediscover clearly the connections between politics, social policy and social services. The challenge for social workers is to understand the political dimensions of social service operations and the connections between the local and global, to feed the professional practice with a policy aimed at achieving social justice and human rights (Lundy, van Wormer, p.737). Ferguson and colleagues, in view of the critical situation facing social workers in the United Kingdom, felt the need to display a protest poster with respect to the condition of social work at risk in the current situation, to abdicate their principles on a number of factors: rampant managerialism, fragmentation of services, economic constraints and lack of resources, increased bureaucracy and workloads, domination of care-management approaches with their performance indicators and the increasing recourse to use of the private sector. The commitment made by these members of "radical social work" is to work together to not lose faith in the possibilities for change, not to lower their head and respond with acquiescence to unethical demands of the profession, and to find in close collaboration with the movements of users' participation the road to building a better world based on social justice. In the text of Ferguson and Woodward (2009) are concrete suggestions to help students and professionals to develop interventions capable of responding to the emotional and material needs of users, with the belief that social work can simultaneously address both people's private and social issues. Much can be learned from the past, such as the example of Jane Addams and Alice Salomon which traces the path of continuing to work as professionals, to be able, paraphrasing the slogan of the International Congress of Hong Kong, "to make a difference".

\section{Bibliography}

Campanini, A., Frost E. (2004), European Social Work. Commonalities and differences, Carocci, Roma.

Campanini, A. Introduction. Educating Social Workers in the context of Europe, in Frost E., Freitas M.J. (eds.), Campanini A. (guest editor) (2007), Social work education in Europe, Carocci, Roma. 
Campanini, A. (2009),I mille volti del tirocinio in Europa in Campanini A. (a cura di) Sistemi di welfare e formazione al servizio sociale in un' Europa che cambia, Unicopli, Milano.

Darlymple, J. \& Burke, B.(1995). Anti-oppressive Practice, Social Care and the Law, Buckingham, Open University Press.

Dominelli, L. (2006), Racialised Identities: New challenges for Social Work Education, in Lyons K., Lawrence, S. (eds), Social Work in Europe: Educating for change, Venture Press, Birmingham.

Dominelli, L. (2002). Anti-oppressive social work. Theory and practice, Hampshire, Palgrave.

Ferguson, I., Woodward, R. (2009). Radical social work in practice. Making a difference, Bristol, The Policy Press.

Friesenhahn,G., (2009), Challenges for social professions in changing European welfare systems, in Oldřich C. et al. (edited by) (2009). Social Professions for a Social Europe. Review- Insight-Prospects, Brno, Ecspress.

Healey, L.(2001), International Social Work:Professional Action in an Interdipendent World,Oxford and New York, Oxford Press.

Juliusdottir, S. (2006) The emerging paradigm shift in social work - In the context of the current reform of social work education. Social work and Society, vol.3, Issue 2, www.socwork.net.

Labonte', C.(2004), La formazione al servizio sociale in Europa e il „Processo di Bologna“in www.aidoss.org.

Lorenz, W. (2006), Perspectives on European Social Work, Barbara Budrich Publishers, Opladen.

Lundy, C.\& Van Wormer, K.(2007), Social and economic justice human right and peace:the challenge for social work in Canada and USA, International Social Work, 50 (6), 727-739.

Lyons, K., Lawrence, S. (eds) (2006), Social Work in Europe: Educating for change, Venture Press, Birmingham.

Martinez-Roman, M. (2007), "Social work education in Europe: The Bologna process and the challenges for the future of social work" in Frost, E., Freitas, M.J. (eds.), Campanini, A. (guest editor), Social work education in Europe, Carocci, Roma.

Morin, E. (1977), La methode, Editions du Seuil, Paris.

Payne, M. \& Askeland G. A., (2008). Globalization and international Social Work, Surrey, Ashgate.

Reichert, E. (ed.), (2007). Challenges in human rights. A social work perspective, New York, Columbia Univeristy Press.

Tesoriero, F.(2006).Personal growth towards intercultural competence trhought and international field education programme, in Asutralian Social Work, 59 (2), 126-140.

Thompson, N., (2006). Anti-discriminatory practice, London, Pallgrave Macmillan.

Walliman, I. (2004), "Bologna e GATS: Ripercussioni in prospettiva a livello universitario", in www.aidoss.org. 